J. Clin. Chem. Clin. Biochem.

Vol. 23, 1985, pp. 225-230

\title{
Spinal Fluid Protein Revisited: A Reappraisal of the Biuret Procedure
}

\author{
By B.G. Blijenberg, H. A. Roetering, L. Zwang and B. Leijnse
}

Academic Hospital Rotterdam-Dijkzigt, Department of Clinical Chemistry, Rotterdam. The Netherlands and

Erasmus University, Department of Chemical Pathology, Rotterdam, The Netherlands

(Received July 9/November 10, 1984)

Summary: In this study our previously described selected method, a biuret procedure with deproteinization, for the determination of spinal fluid protein is thoroughly discussed against the background of the results found with a number of Lowry modifications. The use of various separation techniques, i. e. deproteinization, ultrafiltration and chromatography (HPLC), for protein analysis led to the question as to whether low molecular weight proteins in cerebrospinal fluid play an important role or not with respect to the choice of a selected method for the determination of total protein.

\section{Erneute kritische Überprüfung der Eignung des Biuretverfahrens zur Bestimmung des Liquorproteins}

Zusammenfassung: Unsere kürzlich für die Bestimmung von Liquorprotein beschriebene ausgewählte Methode - ein Biuretverfahren mit Enteiweißung - wird auf der Grundlage von Ergebnissen, die mit mehreren Lowry-Modifikationen erhalten worden waren, erschöpfend diskutiert. Die Anwendung verschiedener Trennverfahren, d. h. Enteiweißung, Ultrafiltration und Hochleistungsflüssigchromatographie in der Proteinanalytik führte zu der Frage, ob Proteine mit niedrigem Molekulargewicht im Liquor eine bedeutende Rolle für die Festsetzung einer ausgewählten Methode zur Bestimmung von Gesamtprotein spielen.

\section{Introduction}

In a previous article on the determination of total protein in cerebrospinal fluid we briefly reviewed a number of techniques with a view to recommending a useful and well standardiżed method (1). To achieve uniformity with the treatment of serum and plasma, and for the sake of a rigidly defined operation, we chose the biuret technique.

Since then our experience with this method has grown, and we have used it in several studies. We still feel that this method was correctly chosen.

Nevertheless our curiosity with respect to the existence of the various Lowry variants remained. A number of them are well documented and, justified by their sensitivity, very popular in biochemistry and clinical chemistry $(2,3,4)$. Moreover, in the above mentioned studies we sometimes found a non explainable difference between our biuret method and our routine method for estimating protein in spinal fluid, which is a Lowry modification (5), although both methods normally correlate very well. Therefore we decided to compare in detail a number of Lowrylike techniques with our biuret method. It seemed appropriate in this comparative study to use various separation techniques, i.e. deproteinization, ultrafiltration and high performance liquid chromatography (HPLC).

\section{Materials and Methods}

Materials

The materials used in this study were, where possible, of p.a. quality, and' handled exactly according to the instructions described in the various procedures (see Methods).

The CSF samples were stored up to two weeks at $+4^{\circ} \mathrm{C}$ before use. 
Methods

A very short description of all methods is given below. For more details the reader is referred to the original articles (see References).

\section{Lowry modification according to Papadopoulos (5)}

Abbreviation: Papadopoulos.

Spinal fluid is diluted with sodium carbonate solution and mixed with copper sulphate solution and, after standing, phenol reagent is added.

\section{Lowry modification according to Peterson(6)}

Abbreviation: Peterson without deproteinization.

Spinal fluid is diluted with water and afterwards this solution is mixed with a reagent containing copper sulphate, potassium tartrate, sodium carbonate and sodium dodecyl sulphate. Finally, phenol reagent is added.
Lowry modification according to Peterson with deproteinization $(6,7)$

Abbreviation: Peterson with deproteinization.

This method closely resembles the foregoing method 2 except that there is no dilution with water, and deproteinization is performed with sodium deoxycholate and trichloroacetic acid solution.

Lowry modification according to Rieder (8)

Abbreviation: Rieder.

Spinal fluid is added to two solutions: one containing copper sulphate and one without copper sulphate ("blank"). After standing phenol reagent is added.

Biuret procedure (1)

Abbreviation: biuret.

Spinal fluid is deproteinized with trichloroacetic acid or phosphotungstic acid. The pellet is dissolved and mixed with biuret reagent.
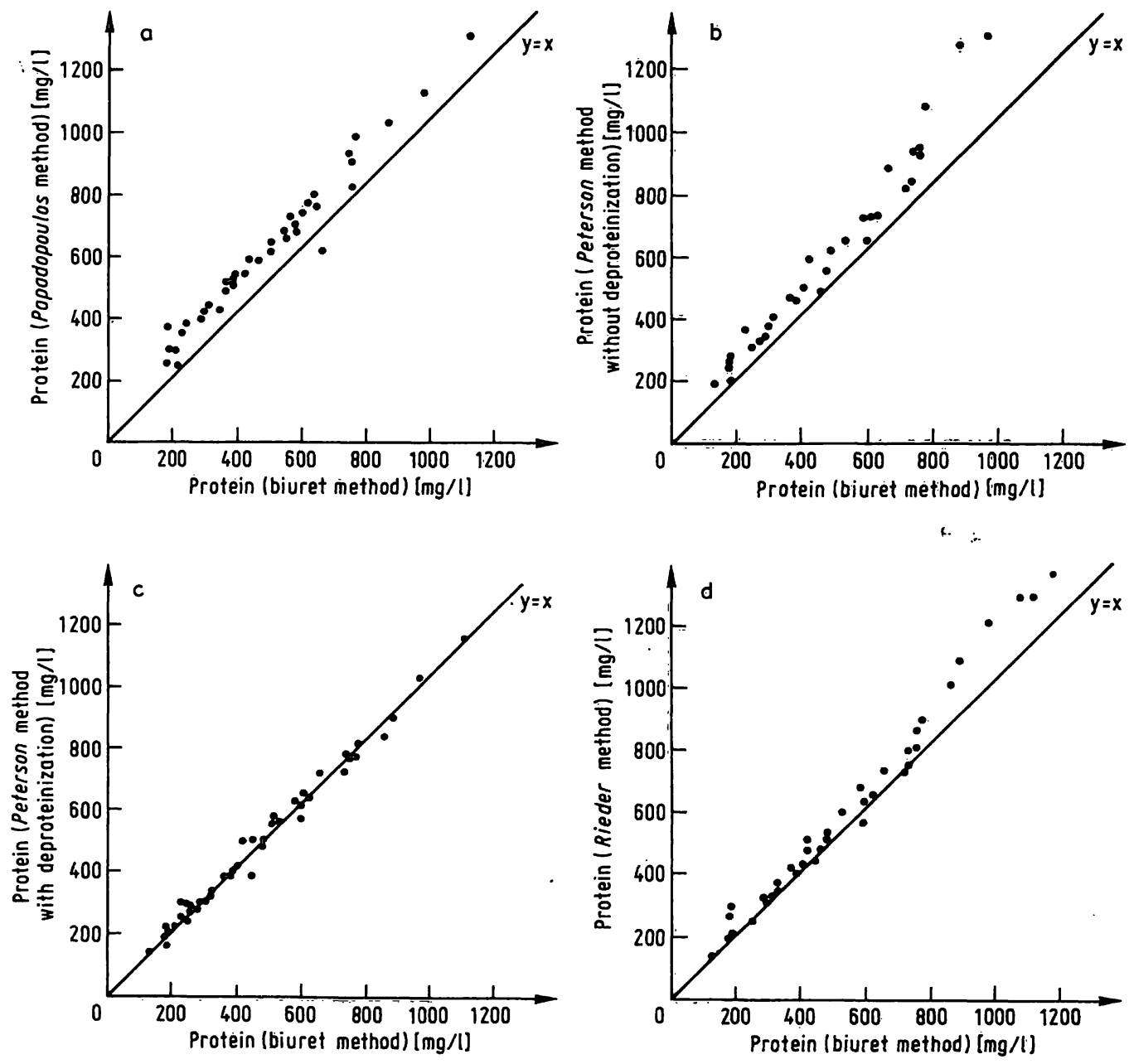

Fig. 1. Split sample comparison between the various Lowry modifications (y-axis) and the biuret method (x-axis). Calibration: human albumin.

The straight line represents the "ideal" correlation $y=x$.

a. Papadopoulos method vs. biuret

$\mathrm{x}=485 \mathrm{mg} / \mathrm{l}, \mathrm{y}=591 \mathrm{mg} / \mathrm{l}, \mathrm{n}=38$.

b. Peterson method without deproteinization vs. biuret $\mathrm{x}=485 \mathrm{mg} / \mathrm{l}, \mathrm{y}=582 \mathrm{mg} / \mathrm{l}, \mathrm{n}=32$.

c. Peterson method with deproteinization vs. biuret $x=478 \mathrm{mg} / \mathrm{l}, \mathrm{y}=465 \mathrm{mg} / \mathrm{l}, \mathrm{n}=44$.

d. Rieder method vs. biuret $\mathrm{x}=530 \mathrm{mg} / \mathrm{l}, \mathrm{y}=578 \mathrm{mg} / \mathrm{l}, \mathrm{n}=38$. 


\section{Ultrafiltration}

An Amicon mini-ultrafiltration cell, model 3, equipped with nitrogen inlet and Diaflo membrane was applied. The membrane was a YM10 type, nominal molecular weight cutoff level 10000 daltons.

High performance liquid chromatography (HPLC)

We used the LKB system developed for protein and peptide separations consisting of a 2150 HPLC Pump, a 2154 Injector, a 2135 Ultro $\mathrm{Pac}^{\star}$ TSKG $3000 \mathrm{SW}$ gel filtration column, $7.5 \times 600 \mathrm{~mm}$, a 2211 Super Rac Fraction Collector and a 215 Variable Wavelength Monitor, detection $280 \mathrm{~nm}$. Elution: 0.1 $\mathrm{mol} / \mathrm{l}$ phosphate buffer-0.05 $\mathrm{mol} / 1 \mathrm{NaCl} \mathrm{pH} 6.7$; flow rate: 0.75 $\mathrm{ml} / \mathrm{min}$ and sample volume: $500 \mu \mathrm{l}$.

\section{Results}

We started the study by comparing the various Lowry modifications described under Materials and Methods with our biuret technique. In the first instance we decided to use the same standard for all methods i.e. human albumin, although we were aware of the difference in colour intensity of the various protein fractions with the Lowry method.

In figure 1 all comparisons are given. Most of the spinal fluid samples were submitted to all the methods of analysis.

It is striking, judging qualitatively, that both Lowry modifications without deproteinization (fig. $1 \mathrm{a}$ and b) are comparable, whereas the other two using deproteinization (fig. 1c) or correction (fig. 1d) are only partially comparable. In trying to find an explanation for these phenomena we decided to study the influence of the standard first. This was only applicable to the Lowry modifications because with respect to the biuret technique the various protein fractions did not show any differences (1).

In figure 2 the results of the various determinations are given.

From figure 2 it seemed clear that the contribution of the standard composition to the differences between the methods with and without deproteinization mentioned in figure 1, could only be moderate if present at all.

So we continued by using the technique of ultrafiltràtion. By means of our routine method for determining protein in spinal fluid (see Mẹthod Papadopoulos) a number of CSF samples were estimated prior to ultrafiltration. After the ultrafiltration these samples were diluted with saline to the same volume as before and again estimated with respect to the protein content. The ultrafiltrate was estimated as well.

\section{All results are given in figure 3.}

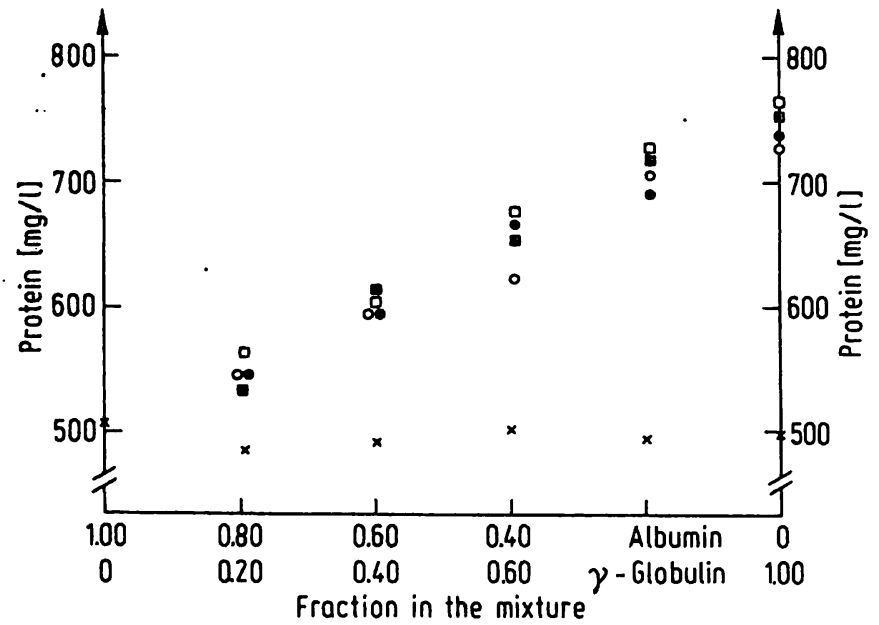

Fig. 2. Absorbance values of various albumin/globulin mixtures.

Albumin $=504 \mathrm{mg} / \mathrm{l}$ human albumin $=$ set point.

Globulin $=498 \mathrm{mg} / \mathrm{l}$ human $\gamma$-globulin

$x=$ biuret method

田 = Lowry modification, Papadopoulos method

$\boldsymbol{\theta}=$ Lowry modification, Peterson method without deproteinization

$\square=$ Lowry modification, Peterson method with deproteinization

$\mathrm{O}=$ Lowry modification, Rieder method

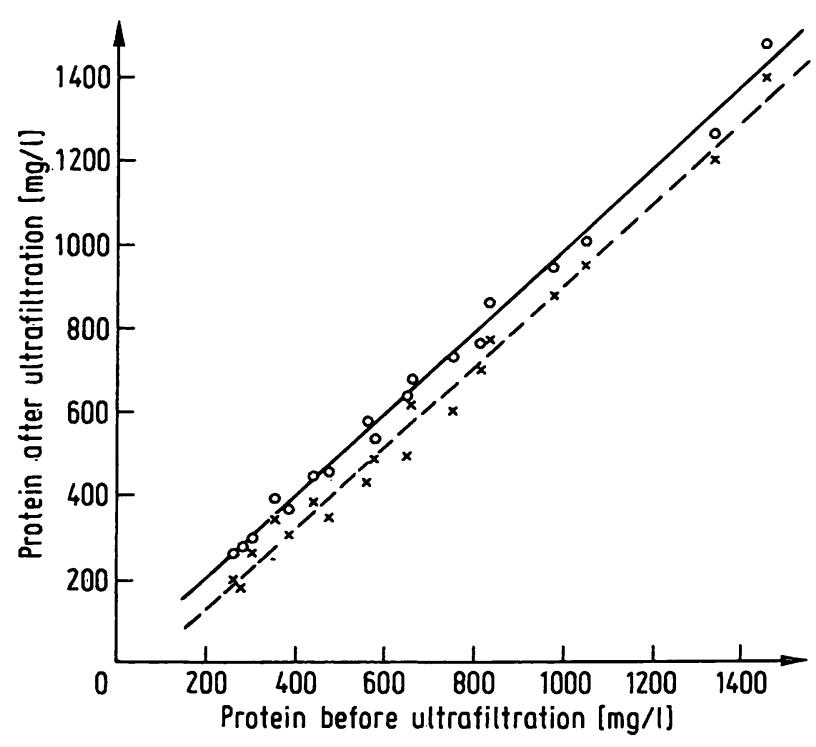

Fig. 3. $x$-axis: protein content prior to ultrafiltration $y$-axis: protein content after ultrafiltration $x$ : residue brought to original volume with saline $\mathrm{O}:$ residue + ultrafiltrate $\mathrm{n}=18$

The results tabulated in figure 3 gave rise to the question as to whether the ultrafiltrate protein content caused the differences mentioned in figure 1. Therefore we felt the need to combine all experiments while making use of the possibilities of high performance liquid chromatography (HPLC). With our instrument and our gel permeation column we were able to make a rough separation between proteins 
of molecular weights ranging from several hundred thousands to about two thousand. An overall chromatogram for spinal fluid is given in figure 4.

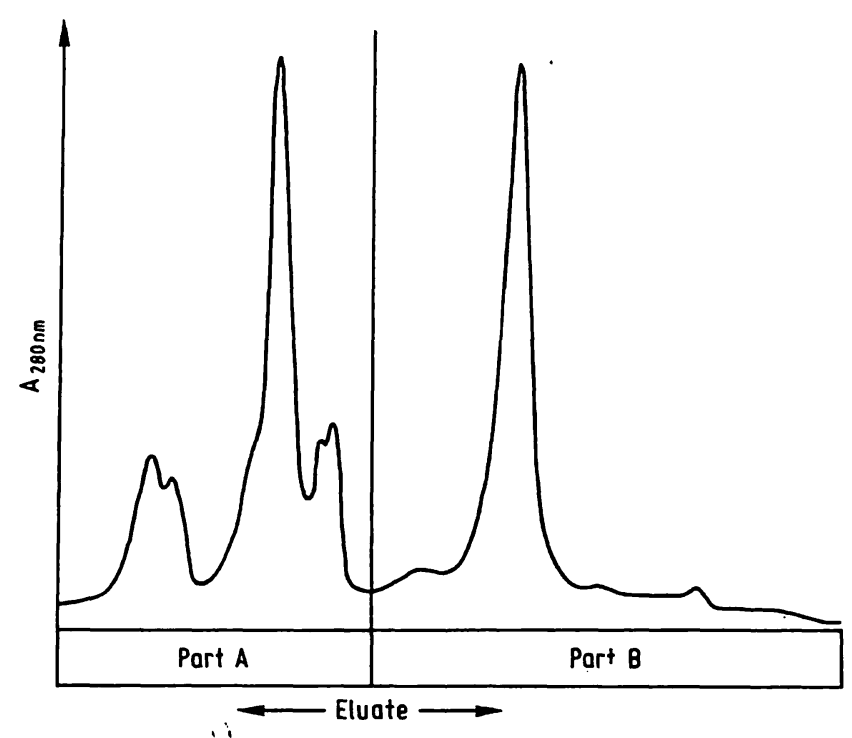

Fig. 4. HPLC-chromatogram of spinal fluid sample.

Part A: proteins, $M_{\mathrm{r}}<20000$

Part B: proteins, $M_{\mathrm{r}}>20000$

2 and $3=$ peaks 2 and 3 covering proteins with $M_{\mathrm{r}}$ around 2000 and 7400 .

Diluted serum, which we used many times in preliminary experiments, showed a comparable chromatogram, with the exception of that part where low molecular weight proteins are recorded (part A). That part proved to be flat.

Then we analysed the supernatant fluids of the various deproteinized spinal fluid samples (deproteinization with phosphotungstic acid as well as trichloroacetic acid). In all experiments deproteinization proved to be nearly complete with two minor exceptions in the higher molecular weight range (see figure 5, part B arrows). we did not study possible differences between phosphotungstic acid and trichloroacetic acid. In figure 5 only the chromatogram with trichloroacetic acid is given because in part $\mathrm{A}$ the phosphotungstic acid complex is superimposed on the rest of the peaks.

The analysis of the ultrafiltrates of spinal fluid gave almost identical pictures with one important exception, i.e. part $B$ of the chromatogram was flat.

It is clear from figures 4 and 5 that we focussed our attention on the substances that showed absorption at $280 \mathrm{~nm}$ and were recorded in part $A$ of the chromatogram. In the first instance we wondered whether these fractions were protein-containing or not. We concentrated them by lyophilization and applied the biuret as well as the Lowry reaction to these samples. In figure 5 the results are given. The protein positive fractions are shaded.

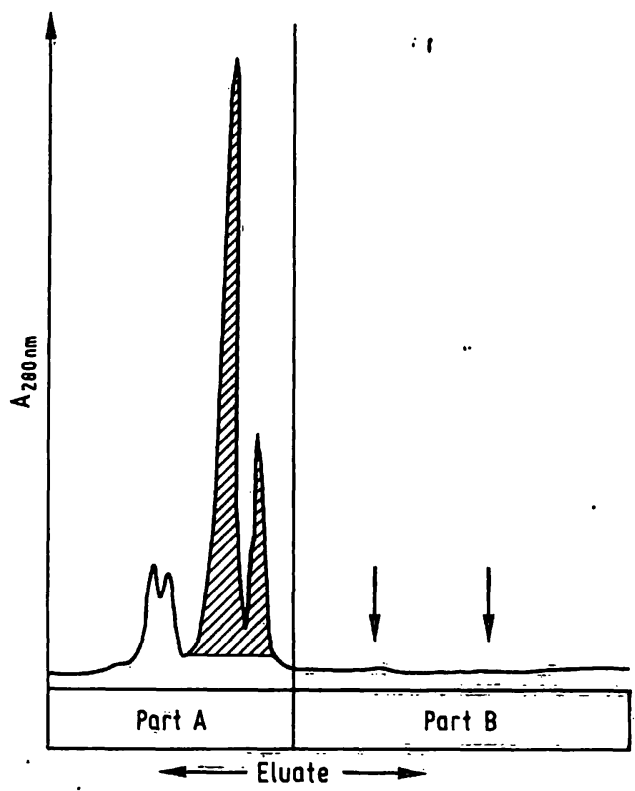

Fig. 5. Chromatogram of remaining spinal fluid' after deproteinization with trichloroacetic acid. Parts A and B: see figure 4.

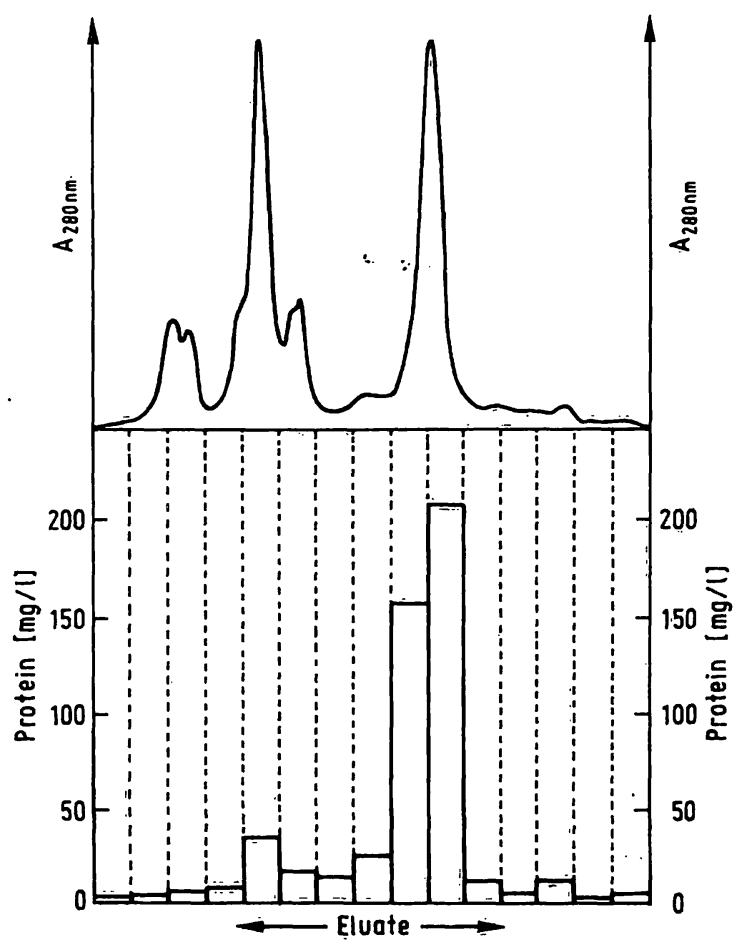

Fig. 6. HPLC-chromatogram of spinal fluid and histogram of protein values of corresponding column fractions (between dotted lines).

Finally, we tried to obtain a quantitative impression of the low molecular weight proteins as compared with the higher molecular weight proteins (part A 
and part B). We applied the most sensitive method i.e. Peterson's Lowry modification without deproteinization (see Methods) to all fractions. The HPLC column was loaded three times with a spinal fluid sample. After fractionation, lyophilization and dissolution in $0.3 \mathrm{ml}$ saline all fractions were measured. In figure $6 \mathrm{a}$ protein histogram in combination with the recorded chromatogram is given.

\section{Discussion}

Reviewing all experiments described under Results as well as the experiments mentioned in our previous article we had to consider the interesting situation of possibly disavowing our suggestion for the use of the biuret method as the reference method for the determination of total protein in cerebrospinal fluid. It is clear from this study that the low molecular weight proteins (see fig. 4, 5 and 6) play an important role in this reconsideration process.

As mentioned earlier, striking advantages of the biuret procedure were the ease of operation, including stability of the reagents, the equality of the colour intensity of the various protein fractions and, last but not least, the uniformity with the serum procedure.

In this study we paid more attention to several Lowry modifications. Not all these modifications were developed especially for spinal fluid analysis but we saw no reason for not applying them.

One important remark has to be made first before studying the results. Because albumin is used as a standard, the Lowry results are slightly incorrect (roughly $10 \%$ too high); this can be seen from figure 2 , and by considering the ratio albumin/globulin in spinal fluid. Therefore a qualitative (semi quantitative) interpretation is more appropriate.

As can be seen in figure 1 interesting differences appear when comparing these Lowry techniques with our biuret method, especially against the background of our findings with high performance liquid chromatography.

There is a striking correlation between the Lowry procedure with deproteinization and our biuret method (fig. 1c); this also seems to be true for the accuracy of the methods. Both the methods without protein precipitation give pictures nearly identical with those from the biuret procedure (see fig. $1 \mathrm{a}$ and b). We felt inclined to ascribe the differences found in all these comparisons to the incompleteness of deproteinization. Indeed there is some confirmation of this view in the chromatograms (fig. 5 and 6). However, the Lowry modification according to Rieder does not use protein precipitation. The only difference between this method and the other two is a blank correction for Lowry positive substances, such as some amino acids and other organic acids. Rieder's method is well correlated with the biuret technique (fig. 1d). Knowing that the low molecular weight proteins are coloured with Lowry's reagent in the Rieder method the experiments shown in figures $1 \mathrm{a}$ and $\mathrm{b}$ and figure $1 \mathrm{~d}$ do conflict to a certain extent, since these proteins are not or only partly precipitated in the biuret procedure. Therefore the question arises of whether this fraction is sufficiently important to influence our biuret procedure. We have not studied the nature and the quantity of this fraction in detail.

Since the cut-off level of the membrane used in the ultrafiltration experiments is about 10000 daltons, the molecular weights of the substances in part A (fig. 4 and 5) are probably lower than 10000 .

According to our experience with a number of proteins of varying molecular weights ( 9 proteins, molecular weights ranging from 3000 to 160000 ) we have estimated the molecular weights of the protein(s) of peak 3 to be about 7400 and those of peak 2 to be about 2000 . We do not yet know how many proteins are involved in the low molecular weight part of the chromatogram $(9,10)$. From the data given in figure 6 it can be calculated that the low molecular weight proteins comprise $15-20 \%$ of the total protein content of spinal fluid in the pool studied. The question arises whether this part has a clinical significance or not. We cannot yet answer this question. It is known that spinal fluid can contain varying amounts of low molecular weight proteins, depending on different pathological conditions $(11,12)$. In fact we have seen differences in the various spinal fluid samples used in this study. These samples were chosen at random. In a future study we hope to investigate this phenomenon further.

Considering all the methodological data, it is clear that two questions still remain, ie. the value of the deproteinization procedure of our own biuret method and the value of the various Lowry procedures. With respect to the first question it became clear from this study that the deproteinization is not quantitative, despite our earlier optimism. We have reasons to believe that the deficit is not the above mentioned $15-20 \%$. However, the exact quantity is a new matter of study, as well as the problem of how to precipitate all proteins, especially all low molecular weight proteins.

Concerning all comparisons with Lowry (fig. 1), there is in our opinion, no reason to consider changing our original methodology and choice of a reference 
method. There is some uncertainty as to what is really measured by the Lowry method, which must be considered a disadvantage. This includes the possible different contributions of the various protein fractions in spinal fluid (fig. 2). Calibration with human serum (diluted) will give somewhat lower results for the Lowry like methods than the results shown in figure 1 while the biuret data are maybe low because of the possible deficiency in the precipitation step. It is very difficult at this stage of the study to make a clear choice.

\section{References}

1. Blijenberg, B. G., Hische, E. A.H., Kamp, H.H., Lamers, K. J. B. \& Souverijn, J. H. M. (1982) J. Clin. Chem. Clin. Biochem. 20, 575-580.

2. Layne, E. (1957) Meth. Enzymol. 3, 447-454.

3. Peterson, G. L. (1983) Meth. Enzymol. 91, 95-119.

4. Peterson, G. L. (1979) Anal. Biochem. 100, 201-220.

5. Papadopoulos, N.M., Hess, W.C., O'Doherty, D. \& McLane, J.E. (1959) Clin. Chem. 5, 569-574.

6. Peterson, G. L. (1977) Anal. Biochem. 83, 346-356.

7. Bensadoun, A. \& Weinstein, D. (1976) Anal. Biochem. 70, $241-250$
This attempt to clarify certain discrepancies has therefore developed into a new study of the protein content of spinal fluid. We hope to report more fully on this aspect in the near future.

\section{Acknowledgements ;}

Thanks are due to Ir. $R$. W. Wulkan and Dr. J. Lindemans for practical help and stimulating comments.

The lyophilisation of the samples was done with the cordial help of colleagues of the Department of Pharmacy (head: Dr. J.W. Meilink)

8. Rieder, H.P. (1966) Klin. Wochenschr. 44, 1036-1040.

9. Walravens, P., Laterre, E. C., Ėstas, A. \& Heremans, J.F. (1967) Clin. Chim. Acta 18, 335-343.

10. Artiss, J. D., Thibert, R. J. \& Zak, B. (1981) Clin. Biochem. 14, 32-38.

11. Cooper, E. H., Turner, R., Johns, E. A., Lindblom, H. \& Britton, V.J. (1983) Clin. Chem. 29, 1635-1640.

12. Post, R.M., Gold, P., Rubinow, D. R., Ballenger, J.C., Bunney, W.E. \& Goodwin, F. K. (1982) Life Sciences. 31, $1-15$.

Dr. B. G. Blijenberg

Academic Hospital Rotterdam-Dijkzigt,

Department of Clinical Chemistry,

Dr. Molewaterplein 40,

NL-3015 GD Rotterdam 